\title{
Behavioural avoidance of acidified water by juveniles of four commercial fish and prawn species with migratory life stages
}

\author{
Frederieke J. Kroon* \\ NSW Fisheries, Port Stephens Fisheries Centre, Private Bag 1, Nelson Bay, New South Wales 2315, Australia \\ Present address: CSIRO Land and Water, Long Pocket Laboratories, 120 Meiers Road, Indooroopilly, \\ Queensland 4068, Australia
}

\begin{abstract}
Impacts on aquatic ecosystems resulting from acute exposure to acid sulfate soil discharge are well documented. However, less is known about the long-term impacts of chronic acid sulfate discharge. Such discharge may create barriers to movement, potentially affecting migration of fish and invertebrate species, including commercial species. Avoidance of such discharges by adults may affect spawning migrations, while similar behaviour by juveniles may affect migration to nursery habitats. As a result, the capacity of fish to access important habitats beyond the discharge point may be reduced with potential consequences for stock size. This study examined the possible existence of acid sulfate avoidance behaviour in juveniles of 3 commercial fish species and 1 commercial prawn species. Schools of 10 individuals were given a simultaneous choice between 2 different water qualities in paired channels of a laboratory stream, i.e. preference-avoidance situation. All species avoided acidified water, indicating that chronic acid sulfate discharge has the potential to affect migration of these species in the field. The $\mathrm{pH}$ levels avoided in these experiments were well within the magnitude exhibited by natural systems. Thus, chronic acid sulfate discharge in the field could have a detrimental impact on commercial and recreational fisheries.
\end{abstract}

KEY WORDS: Avoidance behaviour · Acid sulfate soils • Migration · Juveniles · Pagrus · Acanthopagrus $\cdot$ Macquaria $\cdot$ Metapenaeus

\section{INTRODUCTION}

Acid sulfate soils (ASS) are oxidised or unoxidised sulfidic sediments which occur in coastal floodplains around the world (Dent \& Pons 1993). These soils contain iron sulfides, primarily iron pyrite $\left(\mathrm{FeS}_{2}\right)$, which remain stable under reducing conditions below the water table. Natural or artificial drainage of ASS, however, results in the oxidation of pyrite into hydrogen, sulfate and iron (for detailed chemical reactions, see Dent 1986, White et al. 1997). Sulfuric acid, in turn, enhances the breakdown of metal-bearing sediments (Sammut et al. 1996, Preda \& Cox 2001, see also White et al. 1997). Subsequent rain events leach sulfuric acid from sediments and mobilise metals, resulting in a reduction in water quality (Sammut et al. 1996, Roach 1997, Cook et al. 2000, Preda \& Cox 2001).

Discharges of sulfuric acid and associated (trace-) metals can have immediate and severe ecological impacts (Dent 1986). In Australia, extensive fish kills have been reported in both naturally (Brown et al. 1983) and artificially (Callinan et al. 1996, Dawson 2002) drained ASS catchments along the eastern and northern coastlines. These fish kills were generally associated with acidic water $(\mathrm{pH}<5.0)$ and high concentrations of dissolved aluminium (Brown et al. 1983, Hart et al. 1987), but also with very low levels of dissolved oxygen (Dawson 2002). The seasonal occurrence of epizootic ulcerative syndrome (EUS), a cutaneous ulcerative disease affecting freshwater and 
estuarine fish, has also been related to discharge from ASS (Callinan et al. 1996).

Potential long-term impacts on aquatic ecosystems from chronic acid sulfate discharge are less well known. Chronic discharge may create barriers to movement, potentially affecting the migration of fish and invertebrate species (Brown et al. 1981). In Australia, at least $50 \%$ of commercial and recreational target species undertake migrations to and from the sea (Kailola et al. 1993), and could be exposed to movement barriers. Such effects would be particularly severe when chronic discharge coincides both temporarily and spatially with movement patterns of migratory fish and invertebrate species. If adults avoid acid sulfate discharge, spawning migrations may be affected, while migrations to nursery habitats may be affected if juveniles avoid such discharges. As a result, the capacity of habitats beyond the discharge point to act as spawning or nursery areas may be reduced, with potential effects on population genetics and dynamics, including stock size. The population collapse of the Australian bass Macquaria novemaculeata in the Hastings and Manning rivers (New South Wales, Australia), due to recruitment failure, has been partially attributed to acid sulfate discharge (Harris 1989).

In this study, I examined the possible existence of acid sulfate avoidance behaviour in juveniles of 3 commercial fish species (snapper Pagrus auratus, yellowfin bream Acanthopagrus australis, and Australian bass Macquaria novemaculeata) and 1 commercial prawn species (school prawn Metapenaeus macleayi). I examine the hypothesis that chronic acid sulfate discharge affects movement of migratory fish and prawn species, and predict that (1) juvenile fish and prawns can detect a difference in acidity, and (2) juvenile fish and prawns avoid low concentrations of acid, when given a choice. To test these predictions, schools of the focal species were given a simultaneous choice between 2 different water qualities (in this case $\mathrm{pH}$ ) in paired channels of a laboratory stream, thus exposing them to a preference-avoidance situation.

\section{MATERIALS AND METHODS}

Study species. The distributions of the 4 study species overlap with the distribution of ASS catchments in eastern Australia (National Working Party on Acid Sulfate Soils 2000). In addition, the life history, behaviour and demography of these species suggest that they are susceptible to impacts from ASS, including chronic acid sulfate discharge (see species descriptions below). All 4 species contribute significantly to the commercial and recreational fisheries in eastern Australia (Steffe et al. 1996, Kennelly \& McVea 2001), as well as in other states and territories within Australia (Kailola et al. 1993). The contribution of these species to the indigenous fisheries has not been documented.

I attempted to source all experimental juveniles from the field, in particular from the Port Stephens estuary, where the experimental facilities were based. This was possible for 2 species, namely yellowfin bream and school prawn. For the remaining species, insufficient animals could be obtained in the field, so instead I used hatchery-reared juveniles for snapper and Australian bass. Furthermore, I also ran some additional replicate runs using hatchery-reared juvenile yellowfin bream. For all species, I used juveniles of size ranges that correspond with those size ranges at which juveniles would migrate into estuaries and bays (snapper, yellowfin bream, and Australian bass), or migrate from brackish estuarine areas to the ocean (school prawn).

In the following species descriptions, all information is from Kailola et al. (1993), Neira et al. (1998), and references therein, unless otherwise noted.

Snapper: In eastern Australia, snapper Pagrus auratus (Bloch \& Schneider) (family Sparidae) populations spawn offshore (Ferrell \& Sumpton 1997). In New South Wales (NSW), pelagic larvae enter Tuggerah Lakes from August to October, and Lake Macquarie year-round, with a peak abundance occurring in September. Settlement takes place following metamorphosis (12.0 to $13.3 \mathrm{~mm})$, and juveniles adopt a more benthic lifestyle (Foscarini 1988). Juvenile and small adult snapper (6.5 to $19.5 \mathrm{~cm}$ fork length, measured from tip of the snout to center of the fork of the tail; $0+$ and $1+$ year-classes) have been captured in estuaries and bays in NSW and Queensland (Ferrell \& Sumpton 1997).

Juveniles were obtained from the Aquaculture Marine Hatchery facilities at the Port Stephens Fisheries Centre (NSW Fisheries, Taylors Beach) from July to September 2001.

Yellowfin bream: Yellowfin bream Acanthopagrus australis (Günther) (family Sparidae) is catadromous, migrating downstream to spawn in the open sea near river entrances. In NSW, spawning occurs during late autumn and winter. Larvae enter Tuggerah Lakes from January to May, and in September and October, and Lake Macquarie year-round except November, with peak abundances occurring between January and July. Settlement takes place at approximately 13 to $14 \mathrm{~mm}$ total length (TL, measured from tip of the snout to tip of the tail). Postlarvae and small juveniles (10 to $100 \mathrm{~mm}$ ) are found in shallow estuarine areas and appear to be most abundant in Botany Bay in July and October (Blaber \& Blaber 1980, Worthington et al. 1992). In the Clarence River, the highest abundances of juveniles occur in July and September (West \& King 1996, Kroon et al. 2004).

In 2001, juvenile yellowfin bream were captured using a seine net and baited funnel traps in the Port 
Stephens estuary from October to December, and using a seine net in the Myall river in November. From October 2002 to January 2003, juvenile yellowfin bream were captured using bait traps and a seine net in the Port Stephens estuary. In 2002, additional hatchery-reared juveniles were obtained from Glen Searl (Searl Aquaculture, Palmers Island, NSW). Runs were conducted with either wild or hatchery-reared juveniles, but never with a mixture of both. To avoid a potential confounding effect of size (wild juveniles were significantly larger than hatchery-reared juveniles; see Table 1), the behavioural responses of wild and hatchery-reared juvenile bream were analysed separately.

Australian bass: Australian bass Macquaria novemaculeata (Steindachner) (family Percichthyidae) migrates to lower reaches of estuaries to spawn (Harris 1986). In eastern Australia, spawning takes place in brackish water between May and early September (Harris 1986). Metamorphosis takes place at approximately 25 to $30 \mathrm{~mm}$ TL, when larvae are about 3 mo old; small juveniles reach about $100 \mathrm{~mm}$ TL in their first year (Harris 1986). Juveniles (20 to $50 \mathrm{~mm}$ TL) migrate from the breeding grounds to upstream habitat through spring and summer (Harris 1986), although this migration can continue through the $0+$ and $1+$ year-classes (Harris 1983).

For this experiment, juvenile Australian bass were sourced from the Aquaculture Marine Hatchery facilities at the Port Stephens Fisheries Centre (NSW Fisheries, Taylors Beach) in October and November in 2001, and in November and December 2002.

School prawn: The school prawn Metapenaeus macleayi (Haswell) (family Penaeidae) is catadromous, migrating to the ocean to spawn. The spawning run takes place during spring/summer and spawning occurs from February to May. In NSW, postlarvae (6 to $8 \mathrm{~mm}$ TL) enter estuaries in summer and early autumn. Juveniles move upstream and generally inhabit brackish areas during autumn and winter, although smaller individuals are found up into the freshwater reaches. Adult school prawn predominantly inhabit inshore ocean waters.

Due to their small size, juvenile school prawns could not be captured while entering coastal estuaries. Rather, immature, juvenile school prawns were captured in upper and lower estuaries on their summer migration to the ocean. In 2002, juvenile school prawns were captured using a try-net in the Karuah River during the day (January to March), and the Hunter River at night (February). More juvenile school prawns were captured in the Port Stephens estuary at night, by seine net (February) and dipnet (March to April). In 2003, juvenile school prawns were captured using a commercial otter trawl in the Hunter River from January to March.
Operating procedures. The experiments were conducted using the fluviarium system (Fig. 1) and operating procedures described in detail in Kroon \& Housefield (2003). This system was specifically designed to examine acid avoidance behaviour in juvenile fish and prawns. Here, only a summary of the fluviarium system and operating procedures is provided.

Water was sourced from the Port Stephens estuary for runs with snapper, yellowfin bream and school prawn, while freshwater was used for runs with Australian bass. The Port Stephens area contains drained and un-drained ASS, and it is likely that the discharge of these soils would pass into the local waterways. Analyses of water samples revealed that concentrations of total and dissolved aluminium (Al) and iron (Fe) in both estuarine and freshwater supplies were typical of waterways exposed to acid sulfate discharge (estuarine water, total $\mathrm{Al}=0.13 \mathrm{mg} \mathrm{l}^{-1}$, dissolved $\mathrm{Al}<$ $0.005 \mathrm{mg} \mathrm{l}^{-1}$, total $\mathrm{Fe}=0.103 \mathrm{mg} \mathrm{l}^{-1}$, dissolved $\mathrm{Fe}=$ $0.01 \mathrm{mg} \mathrm{l}^{-1}$; freshwater, total $\mathrm{Al}=1.068 \mathrm{mg} \mathrm{l}^{-1}$, dissolved $\mathrm{Al}=0.124 \mathrm{mg} \mathrm{l}^{-1}$, total $\mathrm{Fe}=0.01 \mathrm{mg} \mathrm{l}^{-1}$, dissolved $\mathrm{Fe} \leq 0.005 \mathrm{mg} \mathrm{l}^{-1}$ ).

Water supplying the system was stored in separate feeder tanks (Fig. 1A), and was continually aerated using air stones to ensure test water was well mixed and to minimise $\mathrm{CO}_{2}$ concentration. The aims of the latter were to obtain stable $\mathrm{pH}$ levels during experiments, and to prevent the formation of free $\mathrm{CO}_{2}$ during acidification of test water, as free $\mathrm{CO}_{2}$ itself can elicit an avoidance response in fish (e.g. Höglund 1961, Jones et al. 1985a). In control runs, untreated water was added to both lateral halves of the fluviarium (Fig. 1B). In experimental runs, untreated water was added to one lateral half, while a sulfuric acid solution was continuously added to the supply line of the other half to regulate levels of acidity, using Mazzei injectors (Fig. 1A). This enabled constant pH control in the fluviarium. To establish and maintain a laminar flow in the system, the fluviarium contained 3 diffusers, 1 separator and 5 foam baffles (Fig. 1B).

During experiments, juvenile fish and prawns were kept in rectangular poly-ethylene holding tanks (400 l) (Fig. 1A). Water in these holding tanks was supplied from the feeder tanks, and was recycled and filtered through a vortex XL Diatomaceous earth filter $(1 \mu \mathrm{m}$ capacity). Tanks had air stones for continuous aeration and were kept indoors in artificial illumination at natural daylight hours at ambient temperature.

Prior to starting a run, 10 naïve juvenile fish or prawns were transferred from a holding tank into the test area of the fluviarium (Fig. 1A) and left to settle for at least 15 min. To prevent visual disturbance from affecting fish or prawn behaviour, the test area was enclosed with black plastic. Time of introduction was noted and continuous video recording was started remotely. 
A

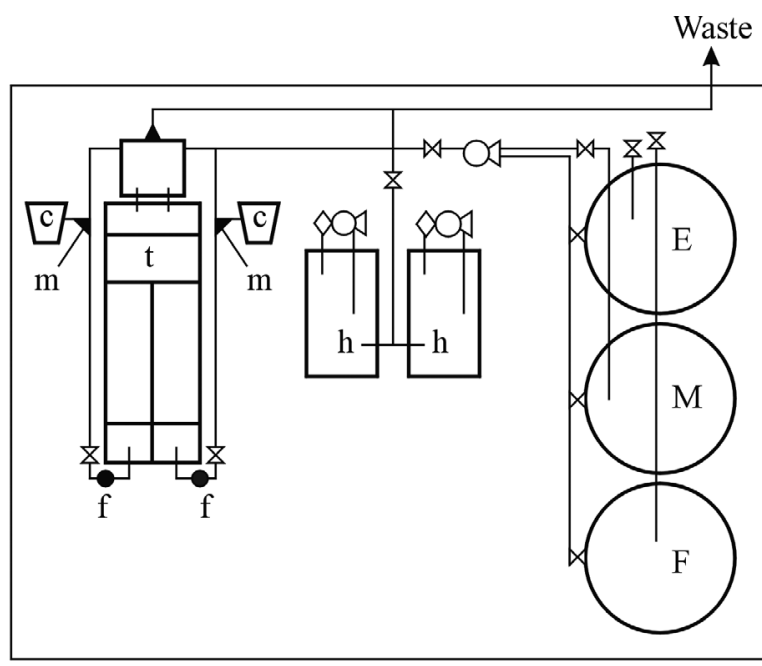

B

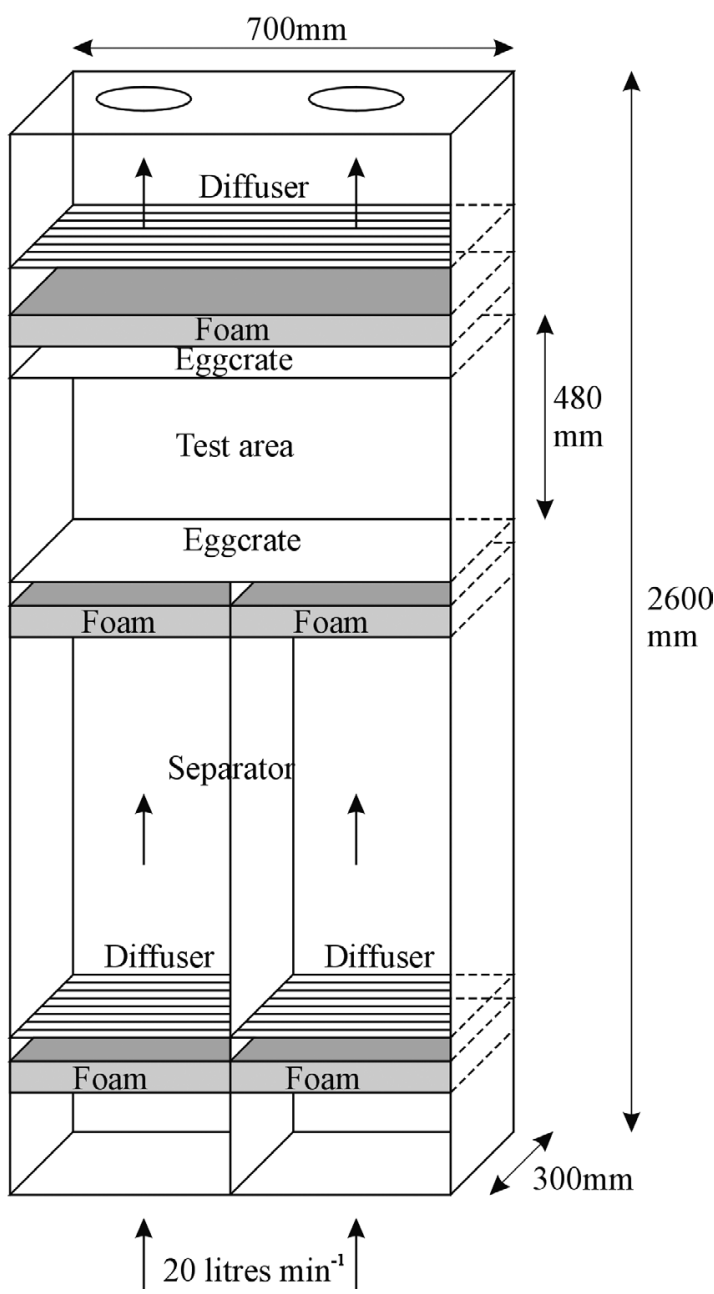

Fig. 1. Fluviarium. (A) General layout of the facility, and (B) detailed outline of the fluviarium. $\mathrm{c}=$ container with acid solution or water, $\mathrm{f}=$ flowmeters, $\mathrm{h}=$ holding tanks, $\mathrm{m}=$ Mazzei injectors, $\mathrm{t}=$ test area, $\mathrm{E}=$ estuarine water input, $\mathrm{F}=$ freshwater input, $\mathrm{M}=$ mixing tank. Dimensions are in $\mathrm{mm}$; arrows in (B) indicate direction of flow. See Kroon \& Housefield (2003) for detailed description
Fifteen min after introduction, a 70 min run was started by turning on the Mazzei injectors. This resulted in water (control run) or sulfuric acid solution (experimental run) being added to the water entering the test area via the experimental channel. To confirm a drop in $\mathrm{pH}, \mathrm{pH}$ profiles of water flowing through the test area were obtained by measuring $\mathrm{pH}$ in the experimental lateral half of the intake area $\left(=\mathrm{pH}_{\mathrm{e}}\right)$ every $30 \mathrm{~s}$. The $\mathrm{pH}$ profile was measured until it stabilised, generally 5 min after the Mazzei injectors were turned on. The $\mathrm{pH}$ of the untreated channel $\left(=\mathrm{pH}_{\mathrm{c}}\right)$ was also checked, and temperature $\left(T\right.$, in $\left.{ }^{\circ} \mathrm{C}\right)$ and salinity (in ppt) were recorded in both channels. Subsequently, the run continued without anyone present to minimise potential observer effects on the animals. For each species, a range of $\mathrm{pH}_{\mathrm{e}}$ values was tested in separate runs.

At the end of each run, all 10 animals were collected from the test area and measured. Standard length (SL, from tip of the snout to caudal peduncle, $1 \mathrm{~mm}$ ) was measured for fish, while TL was measured for prawns $(1 \mathrm{~mm})$. Subsequently, animals were returned to the holding facilities. To ensure that individuals were tested only once, used animals were kept in a separate holding tank. The fluviarium and foam blocks were rinsed and cleaned thoroughly between experiments.

\section{Data analyses}

The assumption was made that if individual runs were conducted and analysed over an appreciable time (i.e. $60 \mathrm{~min}$ ), the average equilibrium behaviour of the 10 individuals in the school would reflect the properties of the run and would not be affected by the initial state of the run. The behavioural response of fish and prawns to 2 different water qualities (i.e. $\mathrm{pH}$ levels) was subsequently assessed as follows. One image from the video footage was grabbed every minute using 'frame grabber' software (Scion LG3), giving 60 images or frames per run (see Fig. 2 for frame examples). To ensure individuals had sufficient time to show a preference, and thus prevent a mean bias over time, the first frame was grabbed $10 \mathrm{~min}$ after a $70 \mathrm{~min}$ run had started. For each frame, the position of each individual (i.e. position of the snout) was determined visually, and the number of individuals in each lateral half of the test area was counted. This procedure was repeated for all 60 images (see Fig. 3). Subsequently, the mean percentage of individuals in each lateral half of the test area was determined for all 60 frames combined. This gave a mean proportion of individuals in the experimental half of the test area over a $60 \mathrm{~min}$ run. This mean proportion was considered the behavioural response of the individuals in that particular run, and was entered as a single replicate in the data analy- 

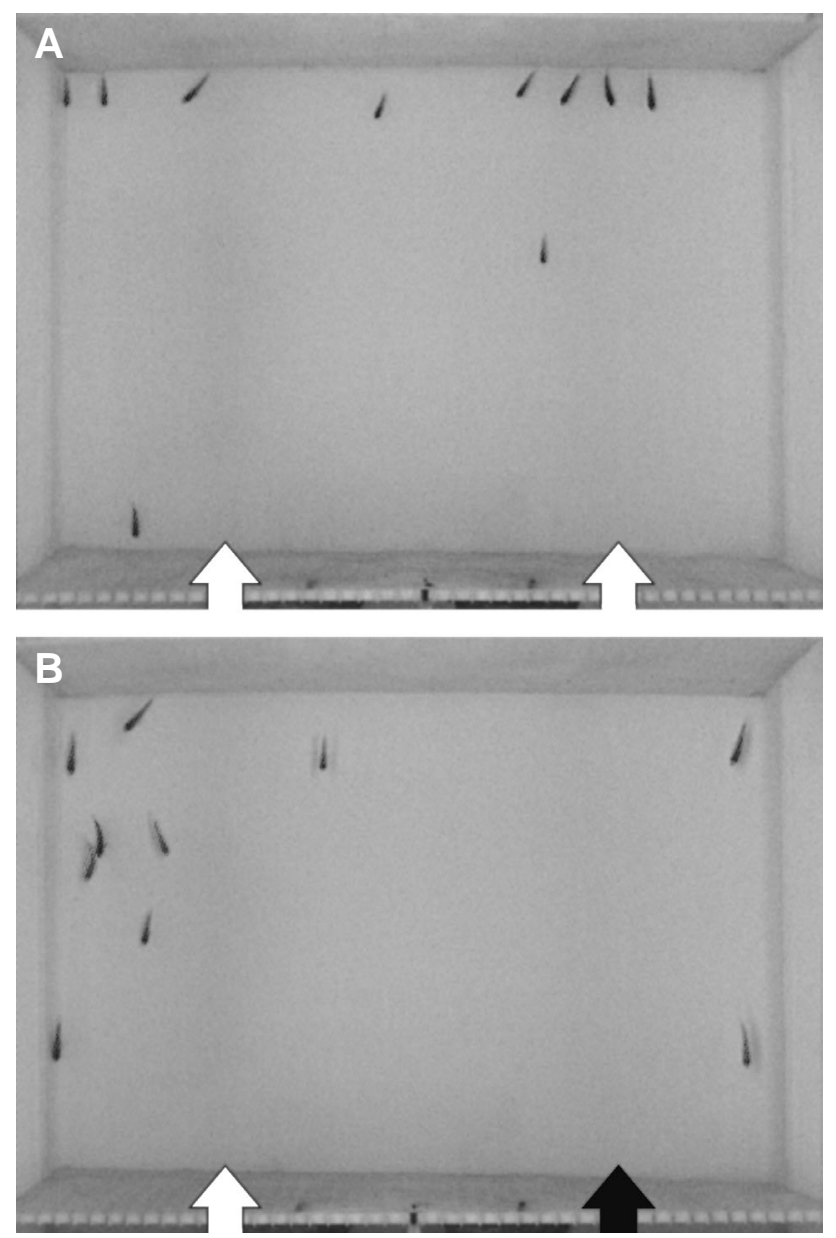

Fig. 2. Pagrus auratus. Juvenile snapper in frames from (A) a control run $\left(\mathrm{pH}_{\mathrm{c}}=8.1\right)$, and (B) an experimental run $\left(\mathrm{pH}_{\mathrm{c}}=\right.$ 8.1, $\mathrm{pH}_{\mathrm{e}}=7.5$ ). In the experimental run, a sulfuric acid solution was added to the right channel. Arrows indicate direction of flow

sis. In control runs, a flip of a coin determined the 'experimental half' of the test area.

The following analyses were conducted for each species separately, and for wild and hatchery-reared Acanthopagrus australis separately. First, to examine whether a behavioural avoidance response existed the individual replicates were plotted against $\mathrm{pH}_{\mathrm{e}}$. A linear regression was fitted to the relationship between the behavioural response and $\mathrm{pH}_{\mathrm{e}}$. The responsiveness of each species to $\mathrm{pH}_{\mathrm{e}}$ was measured as the slope of the fitted lines.

Second, to examine whether other variables may have affected the behavioural responses, principal component analysis (PCA) with Varimax rotation (Manly 1984) was used. Of particular interest were (1) the $\mathrm{pH}$ difference $(\Delta \mathrm{pH})$ between the control $\left(\mathrm{pH}_{\mathrm{c}}\right)$ and experimental $\left(\mathrm{pH}_{\mathrm{e}}\right)$ channel $\left(\Delta \mathrm{pH}=\mathrm{pH}_{\mathrm{c}}-\mathrm{pH}_{\mathrm{e}}\right)$, (2) temperature $(T)$, and (3) salinity of the water used in a run, and (4) mean length of individuals used in a run. These variables could not be held constant in runs for any of the species, since (1) runs were conducted in 2 subsequent years for 3 out of the 4 species (Acanthopagrus australis [wild], Macquaria novemaculeata, Metapenaeus macleayi), and (2) runs within a year were conducted over a period of 2 to 3 mo for all 4 species. In particular, $\Delta \mathrm{pH}$ was included because similar amounts of sulfuric acid added to either estuarine or freshwater did not always result in similar $\mathrm{pH}_{\mathrm{e}}$ due to variations in $\mathrm{pH}_{\mathrm{c}}$ (see Table 2). Thus, $\Delta \mathrm{pH}$ rather than $\mathrm{pH}_{\mathrm{e}}$ could have been the main variable affecting behavioural responses. Preliminary correlation analyses revealed strong and significant correlations between the 5 variables $\left(\mathrm{pH}_{\mathrm{e}}, \Delta \mathrm{pH}\right.$, temperature, salinity, mean length). PCA was used to define variables that could be used to summarise relationships among sets of these interrelated variables, for each species separately. Subsequently, the principal component scores for each run (i.e. actual values of individual cases for the principal components) were used as independent variables in a multiple regression model, with the behavioural response as dependent variable.
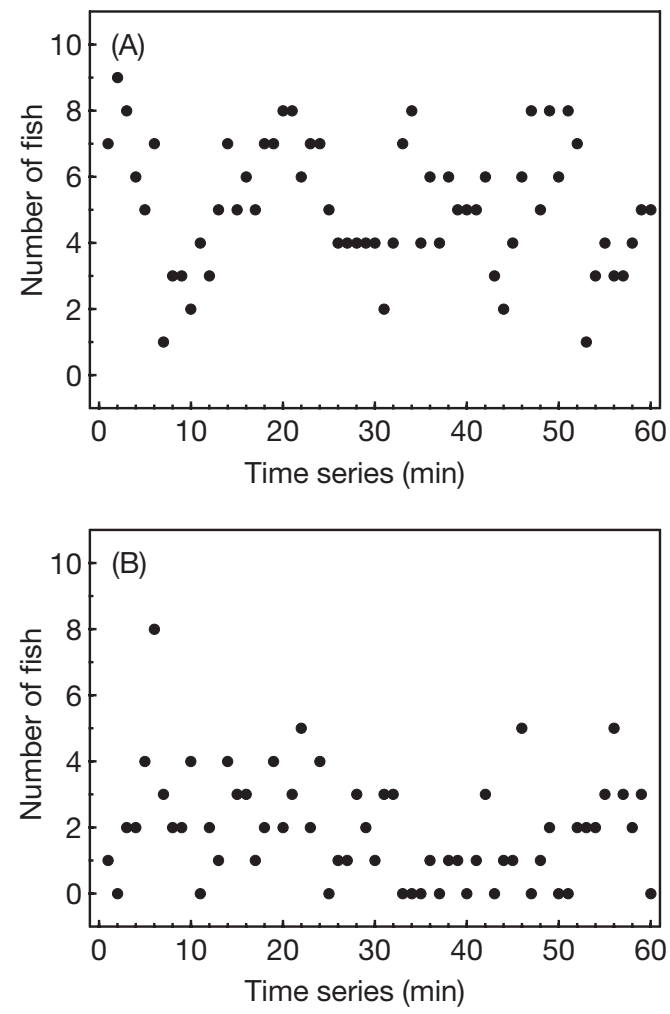

Fig. 3. Pagrus auratus. Number of juvenile snapper in the experimental half of the test area in 60 individual frames from (A) a control run $\left(\mathrm{pH}_{\mathrm{c}}=8.0\right)$, and (B) an experimental run $\left(\mathrm{pH}_{\mathrm{C}}=8.1, \mathrm{pH}_{\mathrm{e}}=7.7\right)$ 
Table 1. Pagrus auratus, Acanthopagrus australis, Macquaria novemaculeata, Metapenaeus macleayi. Length of juvenile fish and prawns, and environmental conditions during preference-avoidance runs. Data are mean $\pm \mathrm{SD}$ (range); n: number of runs; $\mathrm{pH}_{\mathrm{c}}$ : $\mathrm{pH}$ of the untreated channel. Length is total length for M. macleayi and standard length for the other species

\begin{tabular}{|lclccc|}
\hline Species & $\mathrm{n}$ & Length $(\mathrm{mm})$ & $\mathrm{pH}_{\mathrm{c}}$ & Temperature $\left({ }^{\circ} \mathrm{C}\right)$ & Salinity \\
\hline$P$. auratus & 17 & $29 \pm 4(22$ to 37$)$ & $8.1 \pm 0.1(8.0$ to 8.3$)$ & $15.1 \pm 0.8(13.8$ to 16.5$)$ & $30.3 \pm 2.9(20.3$ to 33.4$)$ \\
A. australis (wild) & 24 & $34 \pm 10(22$ to 49$)$ & $8.0 \pm 0.1(7.8$ to 8.2$)$ & $22.9 \pm 2.3(18.3$ to 25.7$)$ & $33.4 \pm 1.8(28.6$ to 36.5$)$ \\
(hatchery-reared) & 22 & $17 \pm 1(16$ to 21$)$ & $8.1 \pm 0.1(8.0$ to 8.3$)$ & $19.5 \pm 1.0(17.7$ to 21.4$)$ & $33.0 \pm 1.7(28.0$ to 34.5$)$ \\
M. novemaculeata & 43 & $19 \pm 2(15$ to 24$)$ & $7.4 \pm 0.4(6.7$ to 8.5$)$ & $23.5 \pm 2.1(17.9$ to 27.3$)$ & $0.5 \pm 0.1(0.2$ to 1.0$)$ \\
M. macleayi & 47 & $85 \pm 7(62$ to 95$)$ & $8.0 \pm 0.1(7.6$ to 8.2$)$ & $24.1 \pm 0.8(22.3$ to 25.9$)$ & $34.4 \pm 2.1(30.1$ to 36.5$)$ \\
\hline
\end{tabular}

\section{RESULTS}

\section{Snapper Pagrus auratus}

Seventeen runs were conducted for snapper in 2001. Mean values $( \pm \mathrm{SD})$ of $\mathrm{pH}_{\mathrm{C}}, T$ and salinity for these runs are given in Table 1. Average mean SL was $29 \mathrm{~mm}$ ( $\pm 4 \mathrm{SD})$, ranging from a mean minimum of $22 \mathrm{~mm}$ to a mean maximum of $37 \mathrm{~mm}$ (Table 1 ).

Avoidance behaviour of juvenile snapper significantly increased with a decrease in $\mathrm{pH}_{\mathrm{e}}\left(F_{1,15}=28.68, \mathrm{r}^{2}=0.66\right.$, $\mathrm{p}=0.0001$; Table 2 ). On average, juveniles were equally distributed across the 2 channels during control runs (mean 47.3\% \pm 10.4 SD, n = 5; Fig. 4A). Juveniles started to avoid the experimental channel when given a choice between water with $\mathrm{pH} 8.1$ and water with $\mathrm{pH} 7.5$ (Fig. 4A). When given a choice between $\mathrm{pH} 8.1$ and 6.9, the average behavioural response was almost $100 \%$ avoidance of the more acidic water ( $\mathrm{pH} \mathrm{6.9)} \mathrm{(Fig.} \mathrm{4A).}$

Preference-avoidance behaviour of juveniles was further analysed by examining the relationships between behavioural response, and water quality/fish size principal components. PCA with Varimax raw rotation identified 2 main trends in the variance of water quality/fish size components: (1) a negative relationship between $\mathrm{pH}_{\mathrm{e}}$ and $\Delta \mathrm{pH}$ (PC 1, accounting for $45 \%$ total variation), and (2) a positive relationship between $T$ and mean SL (PC 2, accounting for $24 \%$ total variation; Table 3). Multiple regression analysis revealed that the behavioural response of juveniles was significantly and positively related to PC 1 (B [nonstandardized regression coefficient $]=15.16, \mathrm{p}=0.001$ ), but not to PC 2 ( $\mathrm{B}=-0.62, \mathrm{p}=0.87$; Table 4$)$.
Table 2. Pagrus auratus, Acanthopagrus australis, Macquaria novemaculeata, and Metapenaeus macleayi. Results of multiple regression, using $\mathrm{pH}$ in the experimental lateral half of the intake area $\left(\mathrm{pH}_{\mathrm{e}}\right)$ as independent variable and behavioural response as dependent variable of preference-avoidance runs conducted with juvenile fish and prawns. B: non-standardized regression coefficient

\begin{tabular}{|c|c|c|c|c|}
\hline Species & B & SE of $B$ & $t$ & $\mathrm{p}$ \\
\hline \multicolumn{2}{|l|}{ P. auratus } & \multicolumn{3}{|c|}{$F_{1,15}=28.68, \mathrm{r}^{2}=0.66, \mathrm{p}<0.0001$} \\
\hline Intercept & -248.41 & 50.75 & \multirow{2}{*}{$\begin{array}{r}-4.9 \\
5.36\end{array}$} & 0.0002 \\
\hline $\mathrm{pH}_{\mathrm{e}}$ & 36.1 & 6.75 & & 0.00008 \\
\hline \multicolumn{2}{|c|}{ A. australis (wild) } & \multicolumn{3}{|c|}{$F_{1,22}=14.76, \mathrm{r}^{2}=0.40, \mathrm{p}<0.0009$} \\
\hline Intercept & -121.73 & 40.78 & -3 & 0.007 \\
\hline $\mathrm{pH}_{\mathrm{e}}$ & 21.73 & 5.66 & 3.84 & 0.0009 \\
\hline \multicolumn{2}{|c|}{ A. australis (hatchery-reared) } & \multicolumn{3}{|c|}{$F_{1,20}=40.60, \mathrm{r}^{2}=0.67, \mathrm{p}<0.00001$} \\
\hline Intercept & -300.8 & 51.67 & -5.82 & 0.00001 \\
\hline $\mathrm{pH}_{\mathrm{e}}$ & 45.14 & 7.09 & 6.37 & 0.000003 \\
\hline \multicolumn{2}{|c|}{ M. novemaculeata } & \multicolumn{3}{|c|}{$F_{1,41}=20.21, \mathrm{r}^{2}=0.33, \mathrm{p}<0.00006$} \\
\hline Intercept & -129.73 & 35.33 & -3.67 & 0.0007 \\
\hline $\mathrm{pH}_{\mathrm{e}}$ & 22.68 & 5.05 & 4.5 & 0.00006 \\
\hline \multicolumn{2}{|c|}{ M. macleayi } & \multicolumn{3}{|c|}{$F_{1,45}=59.42, \mathrm{r}^{2}=0.57, \mathrm{p}<0.000001$} \\
\hline Intercept & -32.12 & 8.78 & -3.66 & 0.0007 \\
\hline $\mathrm{pH}_{\mathrm{e}}$ & 10.33 & 1.34 & 7.71 & $<0.0000001$ \\
\hline
\end{tabular}

\section{Yellowfin bream Acanthopagrus australis}

Wild yellowfin bream

Twenty-four runs were conducted with wild yellowfin bream (11 in 2001, 13 in 2002). Mean values $( \pm \mathrm{SD})$ of $\mathrm{pH}_{\mathrm{C}}, T$ and salinity for these runs are given in Table 1. Average mean SL was $34 \mathrm{~mm}( \pm 10 \mathrm{SD})$, ranging from a mean minimum of $22 \mathrm{~mm}$ to a mean maximum of $49 \mathrm{~mm}$ (Table 1).

Avoidance behaviour of juveniles significantly increased with a decrease in $\mathrm{pH}_{\mathrm{e}}$ $\left(F_{1,22}=14.76, \mathrm{r}^{2}=0.40, \mathrm{p}<0.0009\right.$; Table 2$)$. During control runs ( $\mathrm{n}=2$ ), juveniles were approximately equally distributed across the 2 channels (43.7 and 65.2\%; Fig. 4B). Juveniles started to avoid the experimental channel when given a choice between water with pH 8.1 and water with pH 7.5 (Fig. 4B). This avoidance response increased when given a choice between $\mathrm{pH} 8.0$ and 6.9, to an average of approximately $85 \%$ avoidance when given a choice between pH 8.0 and 6.5 (Fig. 4B). 

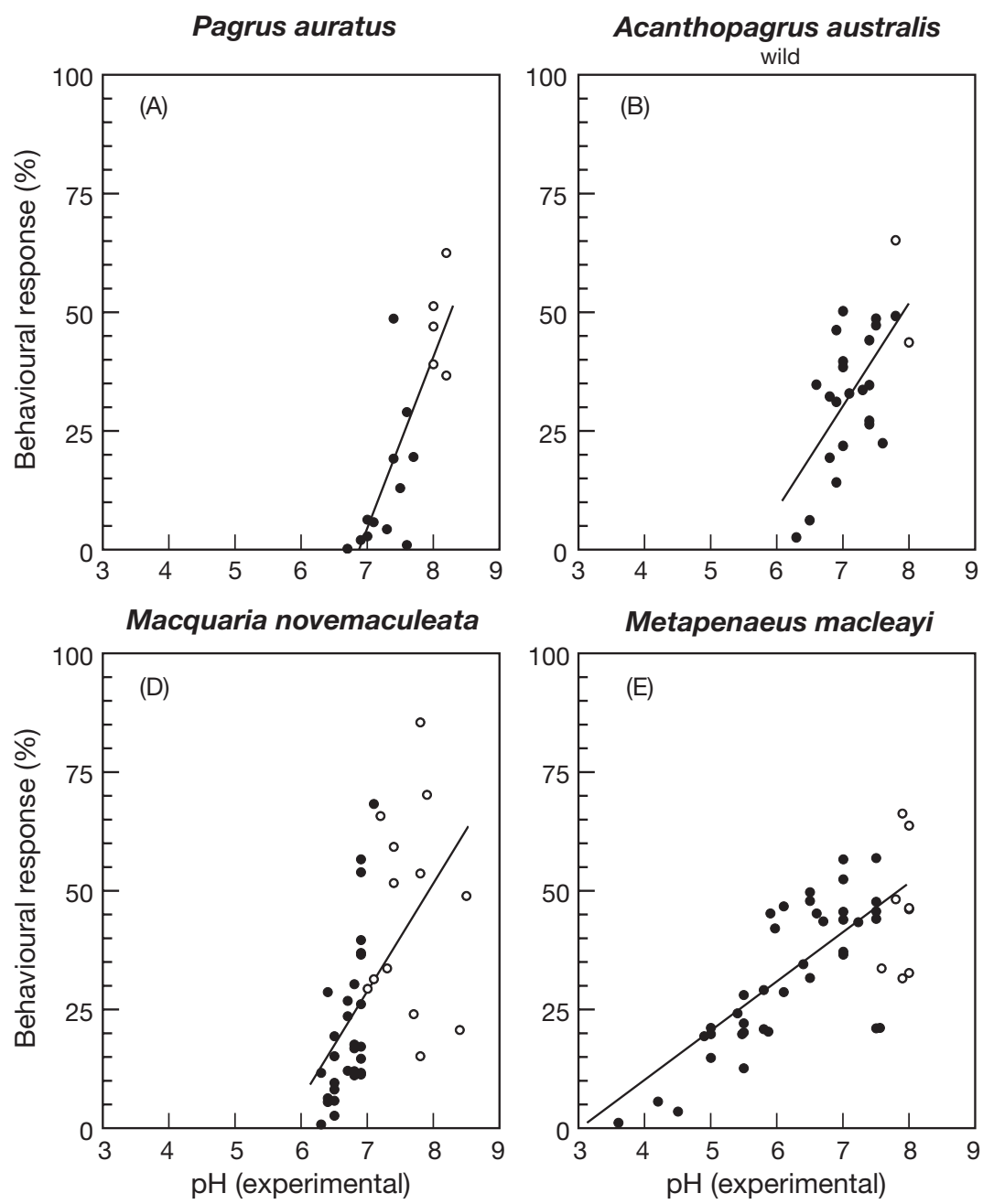

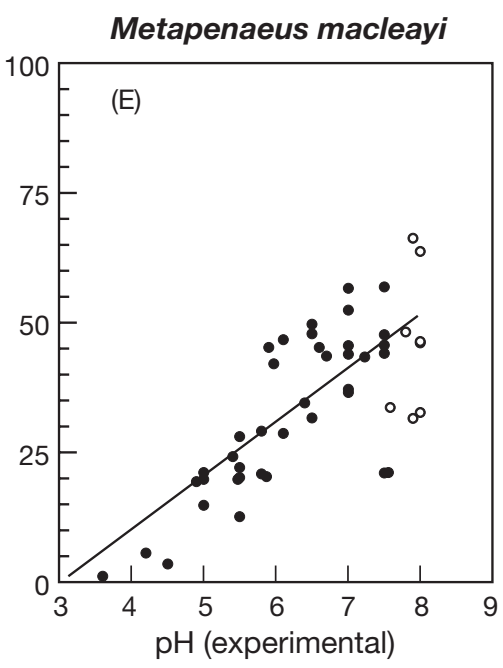

Acanthopagrus australis hatchery reared

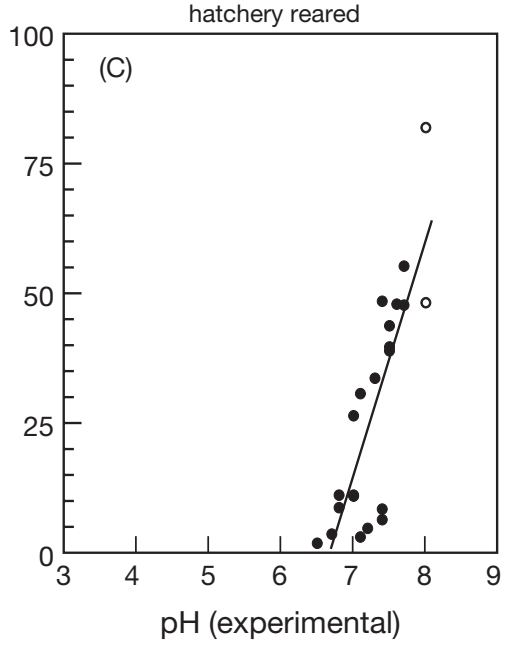

Fig. 4. Pagrus auratus, Acanthopagrus australis, Macquaria novemaculeata, and Metapenaeus macleayi. Behavioural response (\%) of juvenile (A) $P$. auratus, (B) A. australis (wild), (C) A. australis (hatchery-reared), (D) $M$. novemaculeata, and (E) M. macleayi when given a simultaneous choice between 2 water qualities in paired channels of a laboratory stream. O: control runs, $\bullet$ : experimental runs (i.e. sulfuric acid added to 1 channel)
PCA with Varimax raw rotation identified 2 main trends in the variance of water quality/fish size components: (1) a negative relationship between $\mathrm{pH}_{\mathrm{e}}$ and $\Delta \mathrm{pH}$ (PC 1, accounting for $41 \%$ total variation), and (2) a positive relationship between temperature and mean SL (PC 2, accounting for $40 \%$ total variation; Table 3). Multiple regression analysis revealed that the behavioural response of juveniles was significantly and negatively related to PC $1(\mathrm{~B}=-10.85, \mathrm{p}=$ $0.00003)$, but not to PC 2 ( $\mathrm{B}=-3,40, \mathrm{p}=0.11$; Table 4).

\section{Hatchery-reared yellowfin bream}

Twenty-two runs were conducted with hatcheryreared yellowfin bream in 2002. Mean values $( \pm$ SD) of $\mathrm{pH}_{\mathrm{c}}, T$ and salinity for these runs are given in Table 1. Average mean SL was $17 \mathrm{~mm}( \pm 1 \mathrm{SD})$, ranging from a mean minimum of $16 \mathrm{~mm}$ to a mean maximum of 21 mm (Table 1).
Avoidance behaviour of juveniles significantly increased with a decrease in $\mathrm{pH}_{\mathrm{e}}\left(F_{1,20}=40.60, \mathrm{r}^{2}=\right.$ 0.67, p < 0.00001; Table 2). During control runs ( $\mathrm{n}=$ 2 ), juveniles were equally distributed across the 2 channels in one run $(48.3 \%)$, but not in the other $(82.0 \%)$ (Fig. 4C). Exclusion of this datapoint, however, did not markedly change the outcome of the regression $\left(F_{1,19}=29.86, \mathrm{r}^{2}=0.61, \mathrm{p}<0.00003 ; \mathrm{B}=\right.$ $39.43)$, and it was included in subsequent analyses. Juveniles started to avoid the experimental channel when given a choice between water with $\mathrm{pH} 8.1$ and water with $\mathrm{pH} 7.5$ (Fig. 4C). This avoidance response increased when given a choice between $\mathrm{pH} 8.1$ and 7.0 , to almost $100 \%$ avoidance when given a choice between pH 8.0 and 6.6 (Fig. 4C).

PCA with Varimax raw rotation identified 2 main trends in the variance of water quality/fish size components: (1) a negative relationship between $\mathrm{pH}_{\mathrm{e}}$ and $\Delta \mathrm{pH}$ (PC 1, accounting for $43 \%$ total variation), and (2) a negative relationship between salinity and mean length (PC 2, accounting for 38\% total variation; 
Table 3. Pagrus auratus, Acanthopagrus australis, Macquaria novemaculeata, and Metapenaeus macleayi. Principal component loadings examining trends in variance of 5 parameters. Bold: parameters that contribute $>70 \%$ to principal components

\begin{tabular}{|c|c|c|c|c|c|c|c|}
\hline & $\begin{array}{c}\text { Component } \\
(\%)\end{array}$ & $\mathrm{pH}_{\mathrm{e}}$ & $\Delta \mathrm{pH}$ & Salinity & $\begin{array}{c}\text { Temperature } \\
\left({ }^{\circ} \mathrm{C}\right)\end{array}$ & $\begin{array}{l}\text { Mean length } \\
\quad(\mathrm{mm})\end{array}$ & Eigenvalue \\
\hline P. auratus & $\begin{array}{l}\text { PC } 1(45) \\
\text { PC } 2(24)\end{array}$ & $\begin{array}{r}\mathbf{0 . 9 5} \\
-0.01\end{array}$ & $\begin{array}{l}-0.96 \\
-0.04\end{array}$ & $\begin{array}{l}0.53 \\
0.38\end{array}$ & $\begin{array}{r}-0.25 \\
\mathbf{0 . 7 2}\end{array}$ & $\begin{array}{l}0.24 \\
\mathbf{0 . 7 4}\end{array}$ & $\begin{array}{l}2.29 \\
1.16\end{array}$ \\
\hline A. australis (wild) & $\begin{array}{l}\text { PC } 1(41) \\
\text { PC } 2(40)\end{array}$ & $\begin{array}{c}-\mathbf{0 . 9 6} \\
0.1\end{array}$ & $\begin{array}{r}\mathbf{0 . 9 8} \\
-0.04\end{array}$ & $\begin{array}{l}0.39 \\
0.51\end{array}$ & $\begin{array}{r}0.03 \\
\mathbf{- 0 . 9 2}\end{array}$ & $\begin{array}{r}0.15 \\
\mathbf{- 0 . 9 4}\end{array}$ & $\begin{array}{l}2.15 \\
1.91\end{array}$ \\
\hline (hatchery-reared) & $\begin{array}{l}\text { PC } 1(43) \\
\text { PC } 2(38)\end{array}$ & $\begin{array}{r}-\mathbf{0 . 9 8} \\
0.13\end{array}$ & $\begin{array}{l}\mathbf{0 . 9 6} \\
0.02\end{array}$ & $\begin{array}{l}-0.02 \\
-\mathbf{0 . 9 3}\end{array}$ & $\begin{array}{l}0.5 \\
0.38\end{array}$ & $\begin{array}{r}-0.12 \\
\mathbf{0 . 9 4}\end{array}$ & $\begin{array}{l}2.15 \\
1.9\end{array}$ \\
\hline M. novemaculeata & $\begin{array}{l}\text { PC } 1(37) \\
\text { PC } 2(33)\end{array}$ & $\begin{array}{r}-\mathbf{0 . 9 2} \\
0.03\end{array}$ & $\begin{array}{l}\mathbf{0 . 8 2} \\
0.32\end{array}$ & $\begin{array}{l}-0.56 \\
-0.03\end{array}$ & $\begin{array}{l}0.11 \\
\mathbf{0 . 8 6}\end{array}$ & $\begin{array}{l}0.07 \\
\mathbf{0 . 8 9}\end{array}$ & $\begin{array}{l}2.16 \\
1.32\end{array}$ \\
\hline M. macleayi & $\begin{array}{l}\text { PC } 1(42) \\
\text { PC } 2(28)\end{array}$ & $\begin{array}{l}\mathbf{0 . 9 9} \\
0.05\end{array}$ & $\begin{array}{c}-0.98 \\
0\end{array}$ & $\begin{array}{l}0.33 \\
0.53\end{array}$ & $\begin{array}{r}0.14 \\
-\mathbf{0 . 7 1}\end{array}$ & $\begin{array}{l}0.08 \\
\mathbf{0 . 7 8}\end{array}$ & $\begin{array}{l}2.13 \\
1.36\end{array}$ \\
\hline
\end{tabular}

Table 4. Pagrus auratus, Acanthopagrus australis, Macquaria novemaculeata, and Metapenaeus macleayi. Results of multiple regression, using principal components (PC 1 and PC 2) as independent variables and behavioural response as dependent variable of preference-avoidance runs conducted with juvenile fish and prawns

\begin{tabular}{|c|c|c|c|c|}
\hline Species & B & SE of B & $t$ & $\mathrm{p}$ \\
\hline \multicolumn{2}{|l|}{ P. auratus } & \multicolumn{3}{|c|}{$F_{2,14}=7.82, \mathrm{r}^{2}=0.53, \mathrm{p}<0.005$} \\
\hline Intercept & 22.84 & 3.72 & 6.14 & 0.00003 \\
\hline PC 1 & 15.16 & 3.84 & 3.95 & 0.001 \\
\hline PC 2 & -0.62 & 3.84 & -0.16 & 0.87 \\
\hline \multicolumn{2}{|c|}{ A. australis (wild) } & \multicolumn{3}{|c|}{$F_{2,21}=15.39, \mathrm{r}^{2}=0.59, \mathrm{p}<0.00008$} \\
\hline Intercept & 33.91 & 2.01 & 16.9 & $<0.000001$ \\
\hline PC 1 & -10.85 & 2.05 & -5.29 & 0.00003 \\
\hline PC 2 & -3.4 & 2.05 & -1.66 & 0.11 \\
\hline \multicolumn{2}{|c|}{ A. australis (hatchery-reared) } & \multicolumn{3}{|c|}{$F_{2,19}=19.34, \mathrm{r}^{2}=0.67, \mathrm{p}<0.00003$} \\
\hline Intercept & 27.92 & 2.85 & 9.79 & $<0.000001$ \\
\hline PC 1 & -18.12 & 2.92 & -6.21 & 0.000006 \\
\hline PC 2 & -1.12 & 2.92 & -0.38 & 0.71 \\
\hline \multicolumn{2}{|c|}{ M. novemaculeata } & \multicolumn{3}{|c|}{$F_{2,40}=15.19, \mathrm{r}^{2}=0.40, \mathrm{p}<0.00001$} \\
\hline Intercept & 28.64 & 2.49 & 11.52 & $<0.00001$ \\
\hline PC 1 & -13.78 & 2.52 & -5.48 & $<0.00001$ \\
\hline PC 2 & -1.59 & 2.52 & -0.63 & 0.53 \\
\hline \multicolumn{2}{|c|}{ M. macleayi } & \multicolumn{3}{|c|}{$F_{2,44}=33.16, \mathrm{r}^{2}=0.60, \mathrm{p}<0.00001$} \\
\hline Intercept & 34.57 & 1.47 & 23.55 & $<0.00001$ \\
\hline PC 1 & 11.99 & 1.48 & 8.08 & $<0.00001$ \\
\hline PC 2 & 1.49 & 1.48 & 1 & 0.32 \\
\hline
\end{tabular}

$T$ and salinity for these runs are given in Table 1. Average mean SL was $19 \mathrm{~mm}$ ( $\pm 2 \mathrm{SD})$, ranging from a mean minimum of $15 \mathrm{~mm}$ to a mean maximum of $24 \mathrm{~mm}$ (Table 1).

Avoidance behaviour of juveniles significantly increased with a decrease in $\mathrm{pH}_{\mathrm{e}}$ $\left(F_{1,41}=20.21, \mathrm{r}^{2}=0.33, \mathrm{p}<0.00006\right.$; Table 2$)$. On average, juveniles were equally distributed across the 2 channels during control runs (mean $45.4 \pm 21.4 \mathrm{SD}, \mathrm{n}=13$; Fig. 4D). Juveniles started to avoid the experimental channel when given a choice between water with $\mathrm{pH} 7.4$ and water with $\mathrm{pH} 6.9$ (Fig. 4D). This avoidance response increased to an average of approximately 90\% avoidance, when given a choice between $\mathrm{pH} 7.3$ and 6.5 (Fig. 4D).

PCA with Varimax raw rotation identified 2 main trends in the variance of water quality/fish size components: (1) a negative relationship between $\mathrm{pH}_{\mathrm{e}}$ and $\Delta \mathrm{pH}$ (PC 1, accounting for $37 \%$ total variation), and (2) a positive relationship between temperature and mean length (PC 2, accounting for $33 \%$ total variation; Table 3). Multiple regression analysis revealed that the behavioural response of juvenile Australian bass was sig-

Table 3). Multiple regression analysis revealed that the behavioural response of juveniles was significantly and negatively related to $\mathrm{PC} 1$ ( $\mathrm{B}=-18.12, \mathrm{p}=$ 0.000006; Table 4), but not to PC 2 (B =-1.12, $\mathrm{p}=0.71$; Table 4).

\section{Australian bass Macquaria novemaculeata}

Forty-three runs were conducted with Australian bass (8 in 2001, 35 in 2002). Mean values ( \pm SD) of $\mathrm{pH}_{\mathrm{C}^{\prime}}$ nificantly and negatively related to PC 1 ( $\mathrm{B}=-13.78$, $\mathrm{p}<0.00001)$, but not to PC 2 (B = -1.59, $\mathrm{p}=0.53$; Table 4).

\section{School prawn Metapenaeus macleayi}

Forty-seven runs were conducted with school prawn (19 in 2002, 28 in 2003). Mean values $( \pm \mathrm{SD})$ of $\mathrm{pH}_{\mathrm{c} \prime}$ $T$ and salinity for these runs are given in Table 1 . Average mean TL was $85 \mathrm{~mm}( \pm 7 \mathrm{SD})$, ranging from a mean 
minimum of $62 \mathrm{~mm}$ to a mean maximum of $95 \mathrm{~mm}$ (Table 1).

Avoidance behaviour of juveniles significantly increased with a decrease in $\mathrm{pH}_{\mathrm{e}}\left(F_{1,45}=59.42, \mathrm{r}^{2}=0.57\right.$, $\mathrm{p}<0.000001$; Table 2). On average, juveniles were equally distributed across the 2 channels during control runs (mean 46.2 $\pm 13.4 \mathrm{SD}, \mathrm{n}=8$; Fig. 4E). Juveniles started to avoid the experimental channel when given a choice between water with $\mathrm{pH} 7.9$ and water with pH 5.9 (Fig. 4E). This avoidance response increased to an average of approximately $80 \%$ avoidance, when given a choice between $\mathrm{pH} 8.0$ and 5.0 (Fig. 4B).

PCA with Varimax raw rotation identified 2 main trends in the variance of water quality/prawn size components: (1) a negative relationship between $\mathrm{pH}_{\mathrm{e}}$ and $\Delta \mathrm{pH}$ (PC 1, accounting for $42 \%$ total variation), and (2) a negative relationship between temperature and mean length (PC 2, accounting for $28 \%$ total variation; Table 3). Multiple regression analysis revealed that the behavioural response of juveniles was significantly and positively related to PC 1 ( $\mathrm{B}=11.99, \mathrm{p}<0.00001)$, but not to PC 2 ( $\mathrm{B}=1.49, \mathrm{p}=0.32$; Table 4$)$.

\section{DISCUSSION}

The results support the predictions that juvenile fish and prawn can detect a difference in acidity, and avoid low concentrations of acid when given a choice. Juveniles of all 4 species examined avoided acidified water, with snapper showing the strongest avoidance response and school prawn the weakest. Other variables, such as $\Delta \mathrm{pH}, T$, salinity, and mean length of individuals used in a run may have affected the behavioural responses, as they could not be kept constant over the timeframes the experiments were conducted. The results of PCA and multiple regression analyses, however, confirmed that the behavioural response of all 4 species was related to the acidity of the water, and not to the other variables examined (Tables $3 \& 4$ ).

Other components of acid sulfate discharge, such as dissolved aluminium $(\mathrm{Al})$ and iron $(\mathrm{Fe})$, were present in the water used and may have affected the behavioural responses, particularly at lower $\mathrm{pH}$ when concentration and speciation of metals change (Dent 1986, White et al. 1997). Juveniles of some species show stronger behavioural avoidance of acid water with dissolved $\mathrm{Al}$ than of acid water alone, such as juvenile brook charr Salvelinus fontinalis (Gunn \& Noakes 1986) and brown trout Salmo trutta (Åtland 1998). In contrast, no behavioural avoidance response to dissolved $\mathrm{Al}$ was documented at pH 5.0 for juvenile lake charr Salvelinus namaycush (Gunn et al. 1987) and Atlantic salmon Salmo salar (Åtland \& Barlaup 1996). Whether (trace-) metals present in the water used influenced the behavioural responses of the species examined here remains uncertain. However, the water used was sourced from an area containing ASS, and its $\mathrm{Al}$ and Fe content was typical of acid sulfate discharge. Thus, the behavioural response of juveniles observed here would reflect the behaviour that would be expected in the wild.

The results of this study indicate that chronic acid sulfate discharge has the potential to affect migration of the species studied in the field. First, the $\mathrm{pH}$ levels avoided in these experiments were well within the magnitude of concentrations in natural systems (Sammut et al. 1996, White et al. 1997, Preda \& Cox 2001). In addition, the distributions of the 4 study species overlap with the distribution of coastal ASS in eastern Australia (National Working Party on Acid Sulfate Soils 2000). Furthermore, the size range of juveniles used for all 4 species coincides with the size range at which these juveniles may encounter ASS discharge while migrating through a coastal estuary. This suggests that, in the field, the capacity of fish and prawns to access important habitats beyond acid sulfate discharge point may be reduced with potential consequences for stock size.

This study is the first to document acid avoidance behaviour in Australian fish and prawn species. In the laboratory, avoidance behaviour of low pH levels has been documented in fish species in Europe (Höglund 1961, Davies 1991, Åtland \& Barlaup 1996, Åtland 1998), Japan (Nakamura 1986), North America (Jones et al. 1985a,b, Gunn \& Noakes 1986, Gunn et al. 1987, Peterson et al. 1988, Newman \& Dolloff 1995), and New Zealand (West et al. 1997), and in crayfish in North America (France 1984). Most of these studies examined the potential impact of acid rain, and showed avoidance behaviour of $\mathrm{pH}$ levels well within the magnitude of concentrations in acidified systems (Haines 1981). On the other hand, the range of $\mathrm{pH}$ avoided by New Zealand fish was outside that encountered in their natural streams, suggesting that $\mathrm{pH}$ is unlikely to have a major impact on their distribution (West et al. 1997). Field observations of acid avoidance behaviour are scarce; such behaviour is usually inferred from lack of fish in acidic zones (e.g. Johnson \& Webster 1977, Åtland \& Barlaup 1996).

The observed difference in acid avoidance behaviour between the 4 species (Fig. 4) may be related to differences in natural distribution, life history stage, and chemosensory detection of the acid. First, the strength of the species responses may be related to the acid buffering capacity of the water the juveniles occur in. Snapper occur in environments (Kailola et al. 1993, Neira et al. 1998) that would naturally be well buffered against $\mathrm{pH}$ fluctuations. In contrast, juvenile school prawn may have encountered and adapted to fluctua- 
tions in $\mathrm{pH}$, as they generally inhabit brackish and freshwater areas (Kailola et al. 1993, and references therein). The estuarine distribution of juvenile yellowfin bream (Blaber \& Blaber 1980, Worthington et al. 1992) and Australian bass (Harris 1986), as well as the strength of their behavioural responses, is intermediate compared to juvenile snapper and school prawn (Fig. 4). The difference between behavioural responses of wild and hatchery-reared juvenile yellowfin bream (Fig. 4B,C) may be partly due to an effect of rearing environment, although wild juveniles were also significantly larger than hatchery-reared ones (Table 1), and an effect of size cannot be excluded.

Observed differences in behavioural responses between fish and prawns (Fig. 4) may be due to differences in chemosensory detection of acid, given the differences in structure and function of their chemoreceptors (Caprio 1988, Laverack 1988). School prawn often remained in the acidified side of the test area for a prolonged period followed by a quick retreat to the non-acidified side, whereas juveniles of all 3 fish species would rapidly return to the non-acidified side. Despite their relatively slow response, chronic acid exposure is most likely detrimental to survival of school prawn. Growth of the closely related black tiger prawn Penaeus monodon was significantly reduced during chronic exposure to acidified seawater $(\mathrm{pH} \leq$ 5.5) compared to growth at $6.1 \leq \mathrm{pH} \leq 7.8$, and mortality occurred at $\mathrm{pH} \leq 5.1$ (Allan \& Maguire 1992). This poses the interesting possibility that school prawn do not express avoidance behaviour to low concentrations of acid, despite having physiological sensitivity to it.

Behavioural observations on fish and prawns in a laboratory situation may not necessarily be directly applicable to the species' natural habitat. Preference-avoidance behaviour in the field will be affected by a number of other motivational or environmental factors, including reproduction, competition, feeding, predation, as well as water quality, water velocity, and habitat availability. These other factors may override potential avoidance of acid sulfate discharge, especially if there is no physiological cost to do so. For example, the presence of suitable habitat may alleviate strong avoidance behaviour to low acid levels, as has been shown for zinc avoidance by fathead minnows Pimephales promelas (Korver \& Sprague 1989).

The avoidance response of fish and prawn species to acidified water in the laboratory may also simply reflect a preference for water with a higher $\mathrm{pH}$, and may not necessarily be related to the species' physiological tolerance. This seems unlikely for juvenile snapper, which do not survive exposure to $\mathrm{pH} 7.0$ for a prolonged period of time (S. Fielder, NSW Fisheries, pers. comm.), or for school prawns whose growth and survival may well be affected by chronic exposure to acidic water in a manner similar to the closely related Penaeus monodon (Allan \& Maguire 1992). On the other hand, survival of juvenile Australian bass (20 to $23 \mathrm{~mm}$ ) exposed to $\mathrm{pH} \geq 4.0$ was similar to that in untreated freshwater ( $\mathrm{pH}$ unreported) after $96 \mathrm{~h}$, but was reduced to $65 \%$ when $500 \mu \mathrm{g} \mathrm{l}^{-1}$ aluminium was added (Hyne \& Wilson 1997). I am not aware of any comparative information for yellowfin bream. In general, the $\mathrm{pH}$ at which reproductive failure may occur in the laboratory is in agreement with the field $\mathrm{pH}$ known to affect a species (Haines 1981). Moreover, the lowest $\mathrm{pH}$ in the field is generally higher than the lowest $\mathrm{pH}$ in the laboratory, possibly because of the presence in the field of associated (trace-) metals (Haines 1981). Thus, it is highly likely that the $\mathrm{pH}$ levels shown to cause avoidance behaviour in this study affect migration patterns of the species studied in the field.

In summary, the results demonstrate that chronic acid discharge can create barriers to movement potentially affecting the migration of fish and invertebrate species. If juvenile snapper, yellowfin bream and Australian bass avoid such discharges, large parts of potential nursery habitat may not be used. If juvenile school prawns avoid such discharges on their migration to the ocean, spawning migrations may be disrupted. This may eventually result in recruitment failure in areas with acid sulfate discharge, and could potentially affect population dynamics and stock size. Hence, the suggestion that the population collapse of the Australian bass in the Hastings and Manning rivers (New South Wales), due to recruitment failure, can be partially attributed to acid sulfate discharge (Harris 1989) is entirely plausible.

Acknowledgements. Thanks to all NSW Fisheries staff, who helped out with logistics, catching and feeding fish and prawns, or just lent a hand when it was needed. In particular, I am indebted to G. Housefield for fine-tuning the fluviarium to perfection and keeping the fish and prawns swimming. Thanks to A. and G. Hide for catching school prawn, to G. Searl (Searl Aquaculture, Palmers Island, NSW) for providing juvenile yellowfin bream, to R. Liley and H. Olsén for suggestions on methodology, to R. Correll, G. Gordon, and I. Growns for advice on experimental design and statistics, and to $\mathrm{H}$. Buettikofer for improving the figures. Proofreading by $\mathrm{R}$. Liley, P. Munday, H. Olsén, and D. Westcott improved the manuscript. This work is part of grant no. 1998/215 from the Australian Fisheries Research and Development Corporation, and was conducted with permission from NSW Fisheries and NSW Fisheries' Animal Research Authority.

\section{LITERATURE CITED}

Allan GL, Maguire GB (1992) Effects of pH and salinity on survival, growth and osmoregulation in Penaeus monodon Fabricius. Aquaculture 107:33-47

Åtland A (1998) Behavioural responses of brown trout, Salmo trutta, juveniles in concentration gradients of $\mathrm{pH}$ and $\mathrm{Al}-$ a laboratory study. Environ Biol Fish 53:331-345 
Åtland A, Barlaup BT (1996) Avoidance behaviour of Atlantic salmon (Salmo salar L.) fry in waters of low $\mathrm{pH}$ and elevated aluminum concentration: laboratory experiments. Can J Fish Aquat Sci 53:1827-1834

Blaber SJM, Blaber TG (1980) Factors affecting the distribution of juvenile estuarine and inshore fish. J Fish Biol 17: 143-162

Brown SB, Evans RE, Thompson RE, Hara TJ (1981) Chemoreception and aquatic pollutants. In: Hara TJ (ed) Chemoreception in fishes. Elsevier Scientific, Amsterdam, p 363-393

Brown TE, Morley AW, Sanderson NT, Tait RD (1983) Report of a large fish kill resulting from natural acid water conditions in Australia. J Fish Biol 22:335-350

Callinan RB, Sammut J, Fraser GC (1996) Epizootic ulcerative syndrome (red spot disease) in estuarine fish-confirmation that exposure to acid sulfate soil runoff and an invasive aquatic fungus, Aphanomyces sp., are causative factors. In: Smith RJ, Smith HJ, ASSMAC (Acid Sulfate Soils Management Advisory Committee) (eds) Proceedings of the 2nd National Conference on Acid Sulfate Soils, Coffs Harbour, NSW, Australia, 5-6 September 1996, p 146-151

Caprio (1988) Peripheral filters and chemoreceptor cells in fishes. In: Atema J, Fay RR, Popper AN, Tavolga WN (eds) Sensory biology of aquatic animals. Springer-Verlag, New York, p 313-338

Cook FJ, Hicks W, Gardner EA, Carlin GD, Froggatt DW (2000) Export of acidity in drainage water from acid sulfate soils. Mar Pollut Bull 41:319-326

Davies JK (1991) Reactions of sand smelt to low $\mathrm{pH}$ sea-water. Mar Pollut Bull 22:74-77

Dawson K (2002) Fish kill events and habitat losses of the Richmond river, NSW Australia: an overview. J Coastal Res 36:216-221

Dent DL (1986) Acid sulphate soils: a baseline for research and development. Institute for Land Reclamation and Improvement Publication 39, Wageningen

Dent D, Pons L (1993) Acid and muddy thoughts. In: Bush R (ed) Proceedings of the 1st National Conference on Acid Sulphate Soils, Coolangatta, NSW, Australia, 24-25 June 1993. CSIRO, NSW Agriculture, p 1-18

Ferrell D, Sumpton W (1997) Assessment of the fishery for snapper (Pagrus auratus) in Queensland and New South Wales. Final Report for the Fisheries Research and Development Corporation No 93/074. NSW Fisheries Research Institute, Cronulla

Foscarini R (1988) A review: intensive farming procedure for red sea bream (Pagrus major) in Japan. Aquaculture 72: 191-246

France RL (1984) Low pH avoidance by crayfish (Orconectes virilis): evidence for sensory conditioning. Can J Zool 63: 258-262

Gunn JM, Noakes DLG (1986) Avoidance of low pH and elevated $\mathrm{Al}$ concentrations by Brook charr (Salvelinus fontinalis) alevins in laboratory tests. Water Air Soil Pollut 30: 497-503

Gunn JM, Noakes DLG, Westlake GF (1987) Behavioural responses of lake charr (Salvelinus namaycush) embryos to simulated acidic runoff conditions. Can J Zool 65: 2786-2793

Haines (1981) Acidic precipitation and its consequences for aquatic ecosystems: a review. Trans Am Fish Soc 110: 669-707

Harris JH (1983) The Australian bass, Macquaria novemaculeata. PhD thesis, University of New South Wales, Sydney

Harris JH (1986) Reproduction of the Australian bass, Mac- quaria novemaculeata (Perciformes: Percichthyidae) in the Sydney Basin. Aust J Mar Freshw Res 37:209-235

Harris JH (1989) The conservation of threatened fishes and their habitats. In: Hicks M, Eiser P (eds) The conservation of threatened species and their habitats. Australian Committee for IUCN (International Union for Conservation of Nature, Canberra, p 190-191

Hart BT, Ottoway EM, Noller BN (1987) Magela Creek System, Northern Australia. 1. 1982-1983 wet season water quality. Aust J Mar Freshw Res 38:261-288

Höglund LB (1961) The reactions of fish in concentration gradients. Rep Inst Freshw Res Drottningholm 43:1-147

Hyne RV, Wilson SP (1997) Toxicity of acid-sulphate soil leachate and aluminium to the embryos and larvae of Australian bass (Macquaria novemaculeata) in estuarine water. Environ Pollut 97:221-227

Johnson DW, Webster DA (1977) Avoidance of low pH in selection of spawning sites by brook trout (Salvelinus fontinalis). J Fish Res Board Can 34:2215-2218

Jones KA, Hara TJ, Scherer E (1985a) Locomotor response by arctic char (Salvelinus alpinus) to gradients of $\mathrm{H}^{+}$and $\mathrm{CO}_{2}$. Physiol Zool 58:413-420

Jones KA, Hara TJ, Scherer E (1985b) Behavioral modifications in arctic char (Salvelinus alpinus) chronically exposed to sublethal pH. Physiol Zool 58:400-412

Kailola PJ, Williams MJ, Stewart PC, Reichelt RE, McNee A, Grieve C (1993) Fisheries resources. Bureau of Resource Sciences, Department of Primary Industries and Energy, and the Fisheries Research and Development Corporation, Canberra

Kennelly S, McVea T (2001) Status of fisheries resources 2000/2001. NSW Fisheries, Cronulla

Korver RM, Sprague JB (1989) Zinc avoidance by fathead minnows (Pimephales promelas): computerized tracking and greater ecological relevance. Can J Fish Aquat Sci 46: 494-502

Kroon FJ, Housefield GP (2003) A fluviarium with controlled water quality for preference-avoidance experiments with fish and invertebrates. Limnol Oceanogr Methods 1:39-44

Kroon FJ, Bruce AB, Housefield GP, Creese RG (2004) Coastal floodplain management in eastern Australia: barriers to fish and invertebrate recruitment in acid sulphate soil catchments. Final Report for the Fisheries Research and Development Corporation No 98/215. NSW Fisheries Conservation Research, Port Stephens Fisheries Centre, Nelson Bay

Laverack MS (1988) The diversity of chemoreceptors. In: Atema J, Fay RR, Popper AN, Tavolga WN (eds) Sensory biology of aquatic animals. Springer-Verlag, New York, p 287-312

Manly BFJ (1984) Multivariate statistical methods. Chapman \& Hall, London

Nakamura F (1986) Avoidance behaviour and swimming activity of fish to detect $\mathrm{pH}$ changes. Bull Environ Contam Toxicol 37:808-815

National Working Party on Acid Sulfate Soils (2000) National strategy for the management of coastal acid sulfate soils. NSW Agriculture, Wollongbar

Neira FJ, Miskiewicz AG, Trnski T (1998) Larvae of temperate Australian fishes. Laboratory guide for larval fish identification. University of Western Australia Press, Nedlands

Newman K, Dolloff A (1995) Responses of blacknose dace (Rhinichthys atratulus) and brook char (Salvelinus fontinalis) to acidified water in a laboratory stream. Water Air Soil Pollut 85:371-376

Peterson RH, Coombs K, Power J, Paim U (1988) Responses of several fish species to $\mathrm{pH}$ gradients. Can J Zool 67: $1566-1572$ 
Preda M, Cox ME (2001) Trace metals in acid sediments and waters, Pimpama catchment southeast Queensland, Australia. Environ Geol 40:755-768

Roach AC (1997) The effect of acid water inflow on estuarine benthic and fish communities in the Richmond river, NSW Australia. Australas J Ecotoxicol 3:25-56

Sammut J, White I, Melville MD (1996) Acidification of an estuarine tributary in eastern Australia due to drainage of acid sulfate soils. Mar Freshw Res 47:669-684

Steffe AS, Murphy JJ, Chapman DJ, Tarlinton BE, Gordon GNG, Grinberg A (1996) An assessment of the impact of offshore recreational fishing in New South Wales waters on the management of commercial fishing. Final Report to Fisheries Research and Development Corporation No

Editorial responsibility: Otto Kinne (Editor-in-Chief), Oldendorf/Luhe, Germany
94/053. NSW Fisheries, Cronulla

West DW, Boubee JAT, Barrier RFG (1997) Responses to $\mathrm{pH}$ of nine fishes and one shrimp native to New Zealand freshwaters. NZ J Mar Freshw Res 31:461-468

West RJ, King RJ (1996) Marine, brackish, and freshwater fish communities in the vegetated and bare shallows of an Australian coastal river. Estuaries 19:31-41

White I, Melville MD, Wilson BP, Sammut J (1997) Reducing acidic discharges from coastal wetlands in eastern Australia. Wetlands 5:55-72

Worthington DG, Ferrell DJ, McNeill SE, Bell JD (1992) Growth of four species of juvenile fish associated with the seagrass Zostera capricorni in Botany Bay, New South Wales. Aust J Mar Freshw Res 43:1189-1198

Submitted: March 2, 2004; Accepted: August 3, 2004 Proofs received from author(s): December 28, 2004 